\title{
CONSERVATION GENETICS OF AN ENDANGERED CATALONIAN CATTLE BREED ("Alberes")
}

\author{
J. Jordana ${ }^{1}$, J. Piedrafita ${ }^{1}$ X. Carre and A. Martell $^{3}$
}

\begin{abstract}
We biochemically analyzed and characterized the genetic structure of a population in danger of extinction ,"Alberes", a local cattle breed of the Catalonian Pyrenees (Spain and France). Ninety-two individuals were analyzed for five polymorphic genetic loci ( $\mathrm{Hb}, \mathrm{Alb}, \mathrm{Tf}, \mathrm{Gc}$ and Ptf2). The animals were grouped according to coat color: Fagina Alberes variety $(\mathrm{N}=39)$ and Black Alberes variety $(\mathrm{N}=53)$. The genetic structures and relationships between these subpopulations and one "outgroup" breed ("Bruna dels Pirineus") were analyzed and compared by using F-statistics. We determined that inbreeding in the Alberes breed is not significant, since negative and nonsignificant $F_{I T}$ and $F_{I S}$ values were obtained. The average genetic differentiation between subpopulations within the Alberes breed was $1.5 \%\left(\mathrm{~F}_{\mathrm{ST}}=0.015 ; \mathrm{P}<0.05\right)$, with an effective number of 4.1 individuals exchanged between subpopulations per generation (gene flow). The results obtained in this study corroborate the potential danger of extinction of the breed. The Black Alberes variety is proposed as the principal nucleus of genetic conservation for this breed, as it seems to show a higher degree of genetic isolation from other foreign populations.
\end{abstract}

\section{INTRODUCTION}

The Alberes is a semi-feral, local cattle breed of the Catalonian Eastern Pyrenees, located in the Natural Park of the Albera Massif, which comprises a wide zone of the regions of Alt Empordà (Spain) and Vallespir (France). Although considered as a single breed, two varieties of the same breed exist, which differ mainly due to coat color (Mascort, 1957). The fawn color variety (Fagina Alberes) is known in South Catalonia (Spain) as the "Fagina" variety, whose name makes reference to the abundance of beaches in the zone, and in North Catalonia (France) it is known as "Massanaise", the place-name derived from the Massané River (Mason, 1988); the second variety is the black color variety (Black Alberes). The "Fagina" variety prevails in the north and the Black variety in the south.

According to several authors (Mascort, 1957; Sánchez Belda, 1984), the two varieties have different origins. The Black Alberes variety, considered as the "primitive" variety in the country, is a direct descendant of the "Iberian Trunk" that includes breeds such as "Negra Andaluza", "Morucha", "Avileña", etc. The Fagina Alberes variety has a more recent origin, coming from repeated matings of individuals of the Black variety with animals of the breeds "Pirenaica" and "Gasconne", mainly. The introduction of animals coming from the "Turdetanus

\footnotetext{
${ }^{1}$ Unitat de Genètica i Millora, Departament de Patologia i de Producció Animals, Facultat de Veterinària, Universitat Autònoma de Barcelona, 08193 Bellaterra, Barcelona, Spain. Send correspondence to J.J. Fax: +343-581-2006; E-mail: jordana@ guara.uab.es

${ }^{2}$ Servei de Millora i Expansió Ramadera (SEMEGA), Diputació de Girona, Girona, Spain.

${ }^{3}$ Oficina Comarcal del Baix Empordà, (D.A.R.P.), La Bisbal, Girona, Spain.
}

Trunk" in the Albera Massif was a consequence of the restocking that was effected in wide areas of the Pyrenees, after the Foot and Mouth Disease epidemic, which wreaked havoc in this region in 1774. The "Turdetanus Trunk" and the "Iberian Trunk" come from the ancestral Bos brachyceros (Sánchez Belda, 1984), which originated in Mesopotamia and Asia Minor and which could have been introduced into Africa and Europe through Egypt and the Strait of Gibraltar.

The Alberes breed is characterized by small-sized and elongated animals, with a straight cranial profile and short half-moon-shaped horns. Mean adult weight is 350 $\mathrm{kg}$ for males, and $275 \mathrm{~kg}$ for females. The breed has a long calving interval and is known for its hardiness and longevity (Simon and Buchenauer, 1993). They grow in a semi-feral status, the females producing enough milk to raise a calf. The killing-out percent is low (35-40\%), and for this reason matings with other breeds of better meat yield have been frequent. Cleaning the forests is an important effect linked to these herds, which helps prevention of forest fires.

Their current census is very reduced. There exist approximately 900 animals. The number of cows mantaining a high degree of racial purity is about 100 for Black Alberes, and 350 for Fagina Alberes. The number of sires is probably reduced to six (two of Black variety and four of Fagina variety). These figures fit the category of an Endangered Breed (100-1,000 females) proposal of the FAO Expert Consultation (Anonymous, 1992) or the category of Endangered status (100-1,000 females) according to the Red Data Book System, which implies that the breed is in danger of extinction (Bodó, 1992). Without action, its effective population size is inadequate to prevent continuing genetic loss in future generations.

At present 6 herds exist, in the Albera Massif, three herds (Espolla, Jonquera and Requesens) in the Alt 
Empordà region (Spain), with 600 cows approximately, and another three (La Sureda, La Vall and Ballsitges) in the Vallespir region (France), with a total of 300 animals.

The objective of the present study is to characterize biochemically and analyze the genetic structure of a limited-size population in possible danger of extinction. An analysis of the intra-racial genetic variability was carried out by subdividing the population into two varieties (Fagina and Black subpopulations). To have a point of reference to compare results, we used the "Bruna dels Pirineus" breed (Pyrenean Brown breed) as an "outgroup". Data from this breed, geographically close to the Alberes individuals and with a majoritary distribution in the area, were obtained from Jordana and Piedrafita (1996).

The results of this analysis are expected to provide us with some insight for taking decisions for the conservation of the breed. These results will allow us to acquire knowledge of the degree of current genetic variability of the breed, of the genetic differentiation that exists between subpopulations and of the gene flow between the two varieties, as well as of the degree of genic introgression of other foreign populations (e.g. "Bruna dels Pirineus" breed) through the study and analysis of the F-statistics of Wright (Nei, 1977; Wright, 1978).

\section{MATERIAL AND METHODS}

Ninety-two blood samples were collected from different individuals, with a high degree of racial purity, belonging to the Alberes cattle breed. The geographical location of this breed is shown in Figure 1. Blood samples were taken with EDTA $2 \mathrm{Na}^{+}$as an anticoagulant and separated into plasma and red blood cells, before being stored at $-20^{\circ} \mathrm{C}$.

To carry out the intra-racial analysis of this population, the randomly sampled animals were assigned to different subpopulations according to two different varieties:

1) Fagina Alberes: A total of 39 individuals coming from four herds: 3 from Spain (29 individuals) and 1 from France (10 individuals).

2) Black Alberes: A total of 53 individuals coming from three herds: 2 from Spain (37 individuals) and 1 from France (16 individuals).

The variability of five genetic loci was detected by means of different electrophoretic techniques. The hemoglobin $(H b)$-red blood cell system was analyzed by horizontal electrophoresis in agarose gel (Gahne and Juneja, 1985). The others were plasma systems: albumin (Alb), detected by horizontal electrophoresis in starch gel (Bortolozzi, 1983); transferrin (Tf), group-specific component $(G c)$ and post-transferrin 2 (Ptf2), typed by horizontal electrophoresis in polyacrylamide gel (Gahne et al., 1977).

The unbiased average expected heterozygosity $\left(\mathrm{H}_{\mathrm{e}}\right.$; Nei, 1978) has been calculated as an indicator of the level of genetic variability:

$$
\mathrm{H}_{\mathrm{e}}=\left(1-\Sigma \mathrm{p}_{\mathrm{i}}^{2}\right) 2 \mathrm{~N} /(2 \mathrm{~N}-1)
$$

where $\mathrm{p}_{i}$ is the frequency of the ith allele $(\mathrm{i}=1 \rightarrow \mathrm{n})$, and $\mathrm{N}$ is the analyzed sample size. The ANOVA test was applied to determine if there were significant differences among all expected heterozygosity means $\left(\mathrm{H}_{\mathrm{e}}\right)$. "Wright's F"

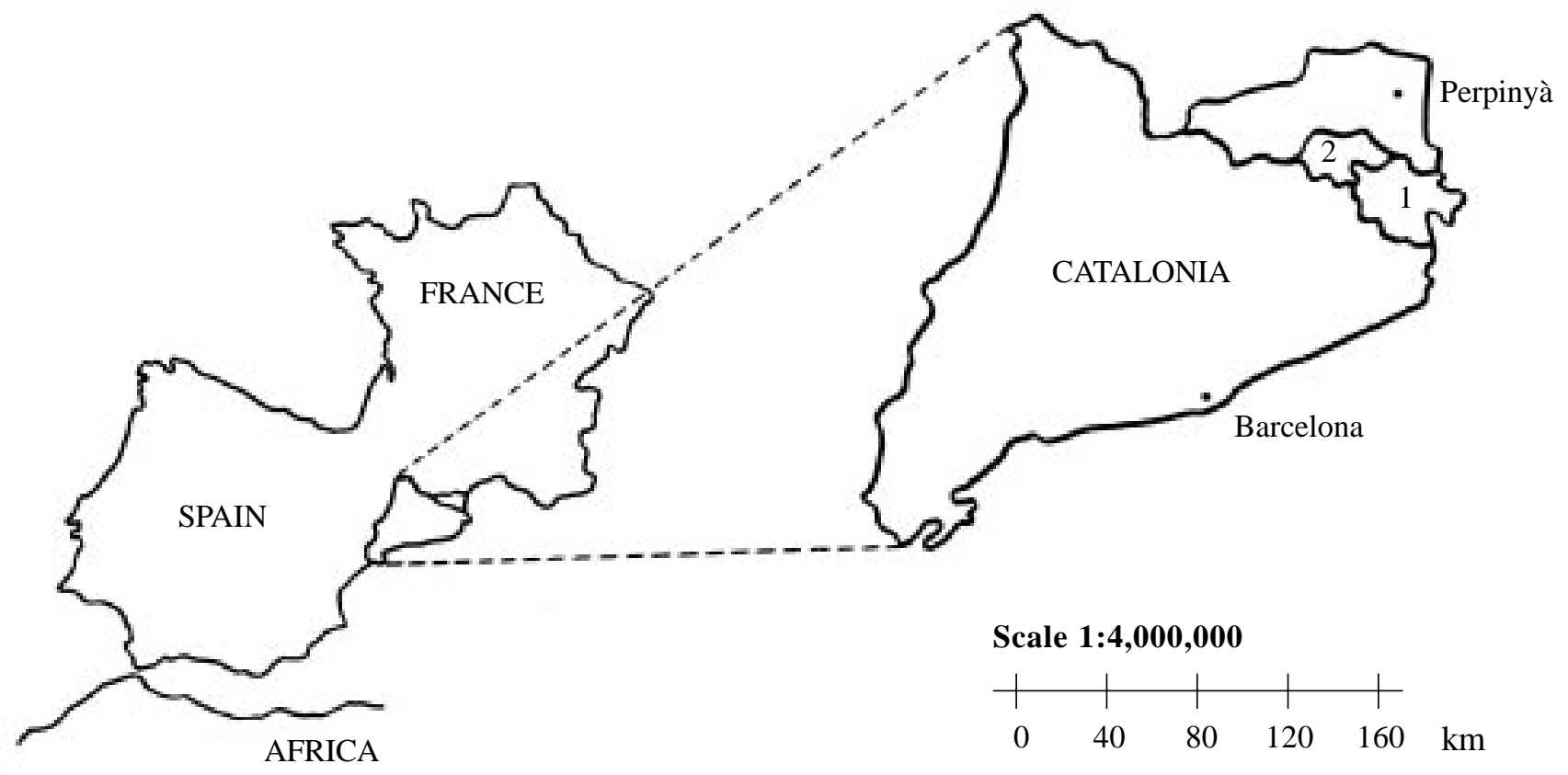

Figure 1 - Geographical location of the “Alberes” breed: 1, Alt Empordà region (Spain); 2, Vallespir region (France). 
(Wright, 1965) for each locus was calculated, giving a measurement of the Hardy-Weinberg equilibrium (HWE) deviation.

The values obtained should not be taken as estimates for the breed, since only five polymorphic loci have been analyzed, resulting in an overestimation of $\mathrm{H}_{e}$ values (Nei, 1987; Hartl and Pucek, 1994). However, these estimates will allow us to compare the different subpopulations of the breed. The $\mathrm{H}_{\mathrm{e}}$ statistic is especially important due to its independence from evolutionary events, such as selection, and from the mating system, although it can be influenced by certain stochastic processes, namely genetic drift (Nygren and Rasmusson, 1980).

Nei's unbiased distance (a modified D for small sample sizes; Nei, 1978), as well as the fixation indices or F-statistics of Wright (1965), modified by Nei (1977) and by Wright (1978), have been calculated as indicators of the genetic differentiation among populations. $\mathrm{F}_{\mathrm{IS}}$ and $\mathrm{F}_{\mathrm{IT}}$ stand for the correlations between two uniting gametes drawn at random from a subpopulation and from the total population, respectively, whereas $\mathrm{F}_{\mathrm{ST}}$ is the correlation between two gametes randomly drawn from each subpopulation. These parameters are related through the following expression:

$$
1-\mathrm{F}_{\mathrm{IT}}=\left(1-\mathrm{F}_{\mathrm{IS}}\right)\left(1-\mathrm{F}_{\mathrm{ST}}\right)
$$

$\mathrm{F}_{\text {IS }}$ and $\mathrm{F}_{\mathrm{IT}}$ statistics measure the excess or the deficit of the average heterozygotes in each subpopulation and in the population as a whole, respectively. $\mathrm{F}_{\mathrm{ST}}$ statistic measures the degree of genetic differentiation among populations. Nei's distance is appropriate for long-term evolution when populations diverge because of drift and mutation. The $\mathrm{F}_{\mathrm{ST}}$ distance, or coancestry distance, is more appropriate for short-term evolution, for divergence due to drift only (Reynolds et al., 1983; Weir, 1990).
The statistical significance of gene frequency differences among populations was tested for each locus by the chi-square test:

$$
\chi^{2}=2 \mathrm{~N} \mathrm{~F}_{\mathrm{ST}}(\mathrm{k}-1)
$$

with (k-1).(s-1) degrees of freedom (d.f.), where $\mathrm{N}$ is the total sample size, $\mathrm{k}$ is the number of alleles for the locus, and $\mathrm{s}$ is the number of subpopulations (Chesser, 1983).

The deviations of $\mathrm{F}_{\mathrm{IT}}$ and $\mathrm{F}_{\mathrm{IS}}$ from zero were tested by the chi-square test ( $\mathrm{Li}$ and Horvitz, 1953; Nei, 1987), with $\mathrm{k}(\mathrm{k}-1) / 2$ degrees of freedom.

$$
\chi^{2}=\mathrm{N} \mathrm{F}^{2}(\mathrm{k}-1)
$$

Computations were performed with the BIOSYS1 package (Swofford and Selander, 1989). The method of cluster analysis using the UPGMA algorithm (Sneath and Sokal, 1973) was applied to the $\mathrm{F}_{\mathrm{ST}}$ estimated values, used as genetic distance.

\section{RESULTS}

The allele frequencies for each electrophoretic locus and population analyzed are shown in Table I. The genic variability statistics are shown in Table II. These values should not be taken as estimates for the breed, since only polymorphic loci have been analyzed; however, these estimates will allow us to compare the different subpopulations of the breed. The average value of the expected heterozygosity per individual and variety was $\mathrm{H}_{\mathrm{e}}=0.325$ $( \pm 0.014)$, ranging from $0.311( \pm 0.056)$ for the Black Alberes and $0.339( \pm 0.063)$ for the Fagina Alberes. The ANOVA test applied to the expected mean heterozygosity did not show significant heterogeneity $(\mathrm{F}$ ratio $=0.135$, not significant, with 1 d.f. between varieties and 8 d.f.

Table I - Allele frequencies for each electrophoretic locus and population analyzed of "Alberes" and "Bruna dels Pirineus" cattle breeds.

\begin{tabular}{|lccccc|}
\hline $\begin{array}{l}\text { Locus } \\
\text { Population }\end{array}$ & $H b$ & $T f$ & Alb & Gc & Ptf2 \\
\hline $\begin{array}{l}\text { Global alberes } \\
(\mathrm{N}=92)\end{array}$ & A: 0.842 & A: 0.288 & A: 0.913 & A: 0.339 & S: 0.217 \\
& B: 0.158 & D: 0.712 & B: 0.087 & B: 0.661 & F: 0.783 \\
$\begin{array}{l}\text { Fagina alberes } \\
\text { (N=39) }\end{array}$ & A: 0.795 & A: 0.282 & A: 0.949 & A: 0.289 & S: 0.321 \\
& B: 0.205 & D: 0.718 & B: 0.051 & B: 0.711 & F: 0.679 \\
$\begin{array}{l}\text { Black alberes } \\
\text { (N=53) }\end{array}$ & A: 0.877 & A: 0.292 & A: 0.887 & A: 0.375 & S: 0.142 \\
$\begin{array}{l}\text { Bruna dels } \text { Pirineus }^{a} \\
\text { (N }=543)\end{array}$ & A: 0.123 & D: 0.708 & B: 0.113 & B: 0.625 & F: 0.858 \\
& B: 0.241 & A: 0.289 & A: 0.952 & A: 0.168 & S: 0.273 \\
& & E: 0.027 & B: 0.048 & B: 0.832 & F: 0.727 \\
\hline
\end{tabular}

$\mathrm{N}$ is analyzed sample size.

${ }^{\mathrm{a}}$ Data for Bruna dels Pirineus from Jordana and Piedrafita (1996). 
Table II - Statistics of genetic variability in the two varieties of "Alberes" cattle breed".

\begin{tabular}{|lcccc|}
\hline Variety & $\begin{array}{c}\text { Mean sample } \\
\text { size per } \\
\text { locus }\end{array}$ & $\begin{array}{c}\text { Mean No. } \\
\text { of alleles } \\
\text { per locus }\end{array}$ & \multicolumn{2}{c|}{ Mean heterozygosity } \\
\cline { 4 - 5 } Fagina Alberes & 38.8 & 2.0 & 0.355 & Expected $^{b}$ \\
& $(0.2)$ & $(0.0)$ & $(0.091)$ & 0.339 \\
Black Alberes & 52.8 & 2.0 & $0.063)$ \\
& $(0.2)$ & $(0.0)$ & $(0.069)$ & $(0.056)$ \\
\hline
\end{tabular}

${ }^{\text {a }}$ Standard errors in parentheses.

${ }^{b}$ Unbiased estimate (Nei, 1978).

Table III - Estimated F-statistics per locus in the "Alberes" cattle breed, and their statistical significances (chi-square tests).

\begin{tabular}{|lcccccc|}
\hline Locus & $\mathrm{F}_{\mathrm{IS}}(1)$ & $\mathrm{F}_{\mathrm{IT}}(2)$ & $\mathrm{F}_{\mathrm{ST}}(3)$ & $\chi^{2}(1)$ & $\chi^{2}(2)$ & $\chi^{2}(3)$ \\
\hline$H b$ & -0.116 & -0.102 & 0.012 & 1.24 & 0.96 & 2.21 \\
$T f$ & -0.110 & -0.110 & 0.000 & 1.11 & 1.11 & 0.00 \\
$A l b$ & -0.104 & -0.090 & 0.013 & 0.99 & 0.74 & 2.37 \\
$G c$ & 0.171 & 0.178 & 0.008 & 2.69 & 2.91 & 1.47 \\
$P t f 2$ & -0.064 & -0.016 & 0.045 & 0.38 & 0.02 & $8.28^{* *}$ \\
\hline Mean & -0.024 & -0.008 & 0.015 & 6.41 & 5.74 & $14.33^{*}$ \\
\hline
\end{tabular}

(*) $\mathrm{P}<0.05 ;(* *) \mathrm{P}<0.01$

Each locus analyzed with 1 degree of freedom.

within varieties). By considering all the individuals as members of a single population (Alberes breed), all the loci showed close agreement with Hardy-Weinberg proportions.

As a genetic differentiation statistic, Nei's unbiased genetic distance between populations was calculated. We used the "Bruna dels Pirineus" breed as an "outgroup". Estimates of genetic distance were D $=0.002$ (Fagina Alberes - Bruna), D = 0.009 (Fagina Alberes Black Alberes) and D = 0.021 (Black Alberes - Bruna).

The results of genetic differentiation estimated by F-statistics analysis are shown in Table III. A general nonsignificant excess of heterozygotes of $2.4 \%$ on average $\left(\mathrm{F}_{\mathrm{IS}}=-0.024, \chi^{2}=6.41\right.$, d.f. $=5$; not significant $)$ existed over all loci for each variety. The excess of heterozygotes in the population as a whole - Alberes breed - was equal to $0.8 \%\left(\mathrm{~F}_{\mathrm{IT}}=-0.008, \chi^{2}=5.74\right.$, d.f. $=5$; not significant $)$. The average genetic differentiation between varieties was $1.5 \%$ $\left(\mathrm{F}_{\mathrm{ST}}=0.015\right)$, a significant value when all the loci are considered $\left(\chi^{2}=6.41\right.$, d.f. $\left.=5 ; \mathrm{P}<0.05\right)$. This heterogeneity is mainly produced by the locus Ptf $2\left(\mathrm{~F}_{\mathrm{ST}}=0.045, \chi^{2}=\right.$ 8.28 , d.f. $=1 ; \mathrm{P}<0.01)$. According to the results of Table III, significant inbreeding in the Alberes breed does not exist, since negative and nonsignificant $\mathrm{F}_{\mathrm{IT}}$ and $\mathrm{F}_{\mathrm{IS}}$ values were obtained.

When we analyzed the two varieties separately (Table IV), we obtained significant $\mathrm{F}_{\mathrm{IS}}$ values for both varieties. In Fagina Alberes an excess of heterozygotes ex- isted $\left(\mathrm{F}_{\mathrm{IS}}=-0.059, \chi^{2}=17.45\right.$, d.f. $\left.=5 ; \mathrm{P}<0.01\right)$; however, in the Black Alberes variety there was a deficit of heterozygotes $\left(\mathrm{F}_{\mathrm{IS}}=0.014, \chi^{2}=13.65\right.$, d.f. $\left.=5 ; \mathrm{P}<0.05\right)$, attributable primarily to the Ptf 2 system $\left(\mathrm{F}_{\text {IS }}=0.456, \chi^{2}=11.02\right.$, d.f. $=1 ; \mathrm{P}<0.001)$.

To calculate the degree of genetic differentiation among particular populations (varieties of the Alberes breed and the outgroup "Bruna dels Pirineus" breed), an analysis was done through F-statistics taking populations in couples (Table V). All $\mathrm{F}_{\mathrm{ST}}$ values of genetic differentiation among pairs were significant. The "Bruna dels Pirineus" breed showed highly significant differences $(\mathrm{P}$

Table IV - Estimated $\mathrm{F}_{\mathrm{IS}}$ values for each locus and variety of "Alberes" cattle breed ${ }^{\mathrm{a}}$, and mean estimates for both varieties.

\begin{tabular}{|lcccc|}
\hline Variety & $\begin{array}{c}\text { Fagina Alberes } \\
(\mathrm{N}=39)\end{array}$ & $\begin{array}{c}\text { Chi-square } \\
\left(\chi^{2}\right)\end{array}$ & $\begin{array}{c}\text { Black Alberes } \\
(\mathrm{N}=53)\end{array}$ & $\begin{array}{c}\text { Chi-square } \\
\left(\chi^{2}\right)\end{array}$ \\
Locus & & & & \\
\hline $\mathrm{Hb}$ & -0.101 & 0.40 & -0.140 & 1.04 \\
$T f$ & -0.266 & 2.76 & 0.043 & 0.10 \\
Alb & -0.054 & 0.11 & -0.128 & 0.87 \\
$G c$ & 0.488 & $9.29^{* *}$ & -0.108 & 0.62 \\
Ptf2 & -0.354 & $4.89^{*}$ & 0.456 & $11.02^{* * *}$ \\
Mean & -0.059 & $17.45^{* *}$ & 0.014 & $13.65^{*}$ \\
\hline
\end{tabular}

${ }^{\mathrm{a}} \mathrm{N}$ is analyzed sample size, and each locus was analyzed with 1 degree of freedom. (*) $\mathrm{P}<0.05$; (**) $\mathrm{P}<0.01 ;(* * *) \mathrm{P}<0.001$. 
Table V - F-statistics analysis between varieties of "Alberes" and the "Bruna dels Pirineus" breed, compared in pairs.

\begin{tabular}{|lccccc|}
\hline Pairs & $\mathrm{F}_{\text {IS }}$ & $\mathrm{F}_{\text {IT }}$ & $\mathrm{F}_{\text {ST }}$ & Chi-square $^{\mathrm{a}}$ & d.f. $^{\mathrm{b}}$ \\
\hline FA-BA $^{\mathrm{c}}$ & -0.024 & -0.008 & 0.015 & $14.33^{*}$ & 5 \\
FA-BP & -0.008 & -0.002 & 0.006 & $32.59^{* * *}$ & 6 \\
BA-BP & 0.030 & 0.054 & 0.025 & $146.62^{* * *}$ & 6 \\
\hline
\end{tabular}

${ }^{\mathrm{a}}$ Significance of $\mathrm{F}_{\mathrm{ST}}$ indicated by the chi-square value: $(*) \mathrm{P}<0.05$; $(* * *)$ $\mathrm{P}<0.001$.

${ }^{\mathrm{b}}$ Degrees of freedom.

${ }^{\mathrm{C} C o d e s:}$ FA $=$ Fagina Alberes $; \mathrm{BA}=$ Black Alberes $; \mathrm{BP}=$ Bruna dels Pirineus (Data for BP from Jordana and Piedrafita, 1996).

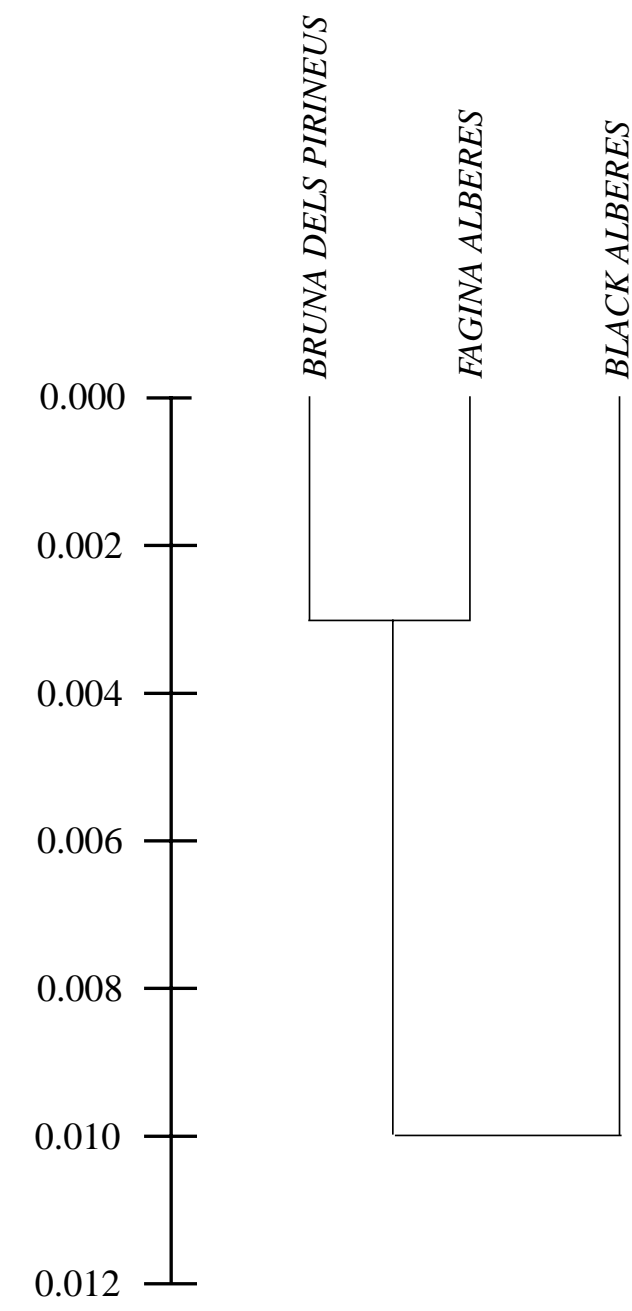

Figure 2 - Phenogram obtained by the UPGMA method using $\mathrm{F}_{\mathrm{ST}}$ distance values, which relates the two varieties of the "Alberes" breed with the outgroup "Bruna dels Pirineus" breed.
$<0.001)$ with the two Alberes varieties. Through cluster analysis methods and by applying the UPGMA algorithm to $\mathrm{F}_{\mathrm{ST}}$ estimates (TableV), the dendrogram of Figure 2 was obtained.

\section{DISCUSSION}

The level of genetic variability of the breed, measured as expected heterozygosity per individual and variety $\left(\mathrm{H}_{\mathrm{e}}=0.325 \pm 0.014\right)$, does not differ significantly from that found in another bovine population, geographically and phylogenetically close to the Alberes breed, as is the "Bruna dels Pirineus" breed $\left(\mathrm{H}_{\mathrm{e}}=0.316 \pm 0.063\right.$; Jordana and Piedrafita, 1996). Comparisons with other breeds would not be suitable, since they should have been typed for the same genetic loci.

A large effective population size $\left(\mathrm{N}_{\mathrm{e}}\right)$ of the Alberes breed might be a possible explanation for its high value of heterozygosity. However, this is not the case since this breed has always been minor and geographically restricted to a small local area of the Catalonian Pyrenees. The absence of the allele $E$ of transferrin locus in this breed (Table I), which was present, although in low frequencies (approximately 0.02-0.15), in many others (Gahne et al., 1977; González et al., 1987; Arranz, 1994), could serve to corroborate this reduced population size (loss of rare alleles for genetic drift in small populations).

The high levels of heterozygosity that both varieties show could be mainly due to the existence of an elevated gene flow between these subpopulations or with other foreign populations, as it has been previously proven that an elevated gene flow maintains high levels of heterozygosity (Waples, 1987; Terauchi, 1990; Ruiz-García, 1994).

We know that inbreeding increases the frequency of homozygotes, and when no other factors exist (Kidd et al., 1980; Foltz, 1981) the inbreeding coefficient of the global population is equal to the $\mathrm{F}_{\mathrm{IT}}$-statistic, $\mathrm{F}_{\mathrm{IS}}$ being the degree of inbreeding within populations (Weir and Cockerham, 1984; Weir, 1990). By considering all the individuals as members of a single population (Alberes breed), we did not observe any deficit of heterozygotes $\left(\mathrm{F}_{\mathrm{IS}}\right.$ and $\mathrm{F}_{\mathrm{IT}}$ were negative and not significant; Table III), which suggests that appreciable inbreeding in this population does not exist. The negative values of these statistics could be explained by the existence of gene flow with other populations (e.g. "Bruna dels Pirineus") and also possibly for the Robertson effect (Robertson, 1965), if there are allele frequency differences between male and female parents; this situation is particularly likely in a polygynous population because of the small number of breeding males.

In analyzing the two varieties separately (Table V), we observed a significant deficit of heterozygotes in the Black variety $\left(\mathrm{F}_{\mathrm{IS}}=0.014 ; \mathrm{P}<0.05\right)$, although not attributable to the inbreeding as the only cause. The inbreeding is 
characterized by equally affecting all the loci, and in this subpopulation the observed deficit of heterozygotes could be attributed in almost exclusive form to one system, the post-transferrin 2 locus (Ptf2). Selection (effect over Ptf2 locus) might be a plausible explanation of the deficit in this variety.

The possible existence of null alleles in the Ptf2 system, not detectable by the electrophoretic techniques applied, should not be discarded as another possible cause of heterozygote deficit. The fact that Black Alberes is considered as a more ancestral or primitive population than Fagina Alberes could support the argument of null alleles in this subpopulation.

The excess of heterozygotes observed in Fagina Alberes $\left(\mathrm{F}_{\mathrm{IS}}=-0.059 ; \mathrm{P}<0.01\right)$ could be explained perfectly by the gene flow existent with other populations, as well as by the Robertson effect.

Although Fagina Alberes does not show any general deficit of heterozygotes, there is a high and significant value of $\mathrm{F}_{\text {IS }}=0.488(\mathrm{P}<0.01)$ for the $G c$ locus (disagreement with HWE). Similar results were obtained by Jordana and Piedrafita (1996) concerning this locus in the "Bruna dels Pirineus" breed, postulating that this Gc locus could perhaps be linked to some morphological or productive trait of selective interest.

Genetic linkage between the loci encoding serum albumin $(A l b)$ and vitamin D-binding protein $(G c)$ has been reported in various species: man (Weitkamp et al., 1966), horse (Sandberg and Juneja, 1978), chicken (Juneja et al., 1982), cattle (Bouquet et al., 1986), and sheep (Erhardt and Simianer, 1993). In horses, linkage disequilibrium was reported between $A l b-G c$ haplotypes and three coat color genes: $(e)$ chestnut, $(R n)$ roan, and $(T o)$ tobiano coat spotting (Andersson and Sandberg, 1982; Bowling, 1987; Bowling and Clark, 1988), so it might be hypothesized that something similar could occur in cattle, between the Gc locus and the brown coat color (coat of "Bruna dels Pirineus" and Fagina Alberes).

The degree of genetic differentiation $\left(\mathrm{F}_{\mathrm{ST}}\right)$ between subpopulations of the Alberes breed was $1.5 \%\left(\mathrm{~F}_{\mathrm{ST}}=0.015\right.$; $\mathrm{P}<0.05)$, indicating that significant subpopulation structure could exist within the population studied (Tables III and V).

This value of genic differentiation $\left(\mathrm{F}_{\mathrm{ST}}\right)$ among subpopulations within the same breed is similar to the values reported for other organisms, for example: black-tailed prairie dogs (Cynomys ludovicianus) from different wards within a population $\left(\mathrm{F}_{\mathrm{ST}}=0.05\right.$; Chesser, 1983); Indians from different villages $\left(\mathrm{F}_{\mathrm{ST}}=0.04\right.$; Nei, 1975); cattle populations from "Bruna dels Pirineus", subdivided by geographical areas $\left(\mathrm{F}_{\mathrm{ST}}=0.016\right.$; Jordana and Piedrafita, 1996); Spanish dogs within different breeds $\left(\mathrm{F}_{\mathrm{ST}}=0.037\right.$; Jordana et al., 1992); human populations from lowland South America and highland New Guinea, subdivided by dialect groups $\left(\mathrm{F}_{\mathrm{ST}}=0.025\right.$ and $\mathrm{F}_{\mathrm{ST}}=0.017$, respectively; Smouse and Long, 1988), among others.
However, the only one locus that contributes to that differentiation is Ptf2 $\left(\mathrm{F}_{\mathrm{ST}}=0.045 ; \mathrm{P}<0.01\right)$, all the rest being nonsignificant (Table III), which indicates the possible existence of an important gene flow between both subpopulations.

By considering all the individuals as a whole (Alberes breed), all the loci showed HWE. In an "island" model, Wright (1978) showed that at equilibrium, $\mathrm{F}_{\mathrm{ST}}$ values allow the estimation of the effective number of individuals, $N_{e} m$, exchanged between populations in each generation (gene flow). The formula of Wright, modified by Takahata (1983) to take into account the number of populations (n), was used:

$$
\mathrm{F}_{\mathrm{ST}}=\left[1 /\left[1+4 \mathrm{~N}_{\mathrm{e}} \mathrm{m}[\mathrm{n} /(\mathrm{n}-1)]^{2}\right]\right]
$$

In applying this formula, the theoretical gene flow $\left(N_{e} m\right)$ between the two varieties was 4.1. Trexler (1988) showed that if $N_{e} m>1$ (in an infinite island model), gene flow is enough to attenuate the genetic differentiation between populations, balanced for migration and gene drift.

When we compared the two varieties of Alberes with the "outgroup" breed "Bruna dels Pirineus", we obtained highly significant differences $(\mathrm{P}<0.001)$ for both comparisons (Table V). However, the interpretation of $\mathrm{F}_{\mathrm{ST}}$ values is radically different.

The degree of genetic differentiation between Fagina Alberes and "Bruna dels Pirineus" was $0.6 \%\left(\mathrm{~F}_{\mathrm{ST}}\right.$ $\left.=0.006, \chi^{2}=32.59 ; \mathrm{P}<0.001\right)$. This high significance for a relatively low value of $\mathrm{F}_{\mathrm{ST}}$ could be due to the large number of analyzed individuals $(\mathrm{N}=590)$. Again, the locus that mostly contributes to that differentiation is the $G c$ system $\left(\mathrm{F}_{\mathrm{ST}}=0.021 ; \mathrm{P}<0.001\right)$, all the rest being non-significant. These results would indicate the existence of an important genetic exchange between both populations $\left(N_{e} m\right.$ $=10.3$. .

Quite the reverse occurs when we compare the Black Alberes - "Bruna dels Pirineus" pair. The degree of genic differentiation in this case is $2.5 \%\left(\mathrm{~F}_{\mathrm{ST}}=0.025, \chi^{2}=\right.$ $146.62 ; \mathrm{P}<0.001)$, all the loci contributing to that differentiation $(\mathrm{P}<0.001$, for each one of them), with the exception of the $T f$ system $\left(\mathrm{F}_{\mathrm{ST}}=0.001 ; \mathrm{NS}\right)$. The theoretical gene flow between both populations was reduced in this case to $N_{e} m=2.4$, substantially less than that found previously.

These relationships are confirmed again in the dendrogram of Figure 2 when we used the $\mathrm{F}_{\mathrm{ST}}$ values as genetic distance. We can see that Fagina Alberes is more closely related with "Bruna dels Pirineus", differentiating themselves perfectly from the Black Alberes variety. The results obtained in this study support the proposed arguments by several authors in relation to the different ancestral origins of the two varieties of Alberes (Mascort, 1957; Sánchez Belda, 1984).

The small population size of this semi-feral local cattle breed $(\approx 450$ females and 6 males, with a high degree of racial purity) makes the establishment of a "Pro- 
gram of conservation and maintenance of animal genetic resources" in this breed a priority. The important gene migration from other breeds, in geographical proximity, mainly through the Fagina Alberes variety, could be another valid argument for the potential danger of a possible absorption of the breed with its subsequent disappearance. We propose the animals of Black Alberes as the principal nucleus of recuperation and conservation for the breed, since they seem to show a higher degree of genetic isolation with other foreign populations. The limited population size, however, might make the effective expansion of this variety difficult in the immediate future.

The allele frequencies of the genetic loci analyzed add information to establish the genetic relationships that this population maintains with other Spanish and European cattle breeds in a similar way as do the studies carried out in this sense by Kidd et al. (1980), González et al. (1987), Arranz (1994), Moazami-Goudarzi et al. (1994), and Medjugorac et al. (1994).

This study constitutes a first approach to the genetic structure and molecular characterization of a limited-size population in potential danger of extinction, as is the Alberes cattle breed. This study could be extended in the near future by using an adequate number of highly polymorphic microsatellite markers following the FAO recommendations (Barker et al., 1993) in order to integrate this information into the FAO Global Data Bank on Domestic Animal Diversity.

\section{ACKNOWLEDGMENTS}

The authors wish to thank the "Departament d'Agricultura, Ramaderia i Pesca" of the "Generalitat de Catalunya" and "SEMEGA" (Diputació de Girona), which financed this study. Also, we thank Chuck Simmons for assistance with the preparation of this manuscript.

\section{RESUMO}

A estrutura génetica de uma população de Alberes, uma raça de gado dos Pirineus catalônicos (Espanha e França) em risco de extinção, foi analisada e caracterizada bioquimicamente. Noventa e dois indivíduos foram analisados para 5 loci genéticos polimórficos ( $H b, A l b, T f$, Gc e Ptf2). Os animais foram agrupados de acordo com a cor do pêlo: variedade Fagina Alberes $(\mathrm{N}=$ 39) e Black Alberes $(\mathrm{N}=53)$. As estruturas genéticas e as relações entre estas subpopulações e uma raça extra ("Bruna dels Pirineus") foram analisadas e comparadas pela estatística F. A endogamia na raça Alberes não foi significante, pois foram obtidos valores $\mathrm{F}_{\mathrm{IT}}$ e $\mathrm{F}_{\mathrm{IS}}$ negativos e não significantes. A diferenciação genética média entre as subpopulações dentro da raça Alberes foi $1,5 \%\left(\mathrm{~F}_{\mathrm{ST}}=0,015 ; \mathrm{P}<0,05\right)$, com um número efetivo de 4,1 indivíduos trocados entre as subpopulações por geração (fluxo de gene). Os resultados obtidos neste estudo confirmaram o perigo potencial de extinção da raça. A variedade Black Alberes é sugerida como o principal núcleo de conservação genética para esta raça, pois parece mostrar maior grau de isolamento genético em relação a outras populações estrangeiras.

\section{REFERENCES}

Andersson, L. and Sandberg, K. (1982). A linkage group composed of three coat color genes and three serum protein loci in horses. J. Hered. 73: $91-94$.

Anonymous (1992). Recommendations of the FAO expert consultation. In: The Management of Global Animal Genetic Resources (Hodges, J. ed.). Food and Agriculture Organization of the United Nations, Rome, pp. 1-24.

Arranz, J.J. (1994). Estudio genético en poblaciones bovinas mediante polimorfismos bioquímicos y de DNA (variaciones puntuales y microsatélites). Ph.D. thesis, Universidad de León, León.

Barker, J.S.F., Bradley, D.G., Fries, R., Hill, W.G., Nei, M. and Wayne, R.K. (1993). An Integrated Global Programme to Establish the Genetic Relationships Among the Breeds of Each Domestic Animal Species. Food and Agriculture Organization of the United Nations, Animal Production and Health Division, Rome.

Bodó, I. (1992). The minimum number of preserved populations. In: The Management of Global Animal Genetic Resources (Hodges, J., ed.). Food and Agriculture Organization of the United Nations, Rome, pp. 91-105.

Bortolozzi, J. (1983). Polimorfismo da albumina sérica em bovinos da raça Canchim. Rev. Ciênc. Bioméd. 4: 1-6.

Bouquet, Y., Van de Wege, A., Van Zeveren, A. and Varewyck, H. (1986). Evolutionary conservation of the linkage between the structural loci for serum albumin and vitamin D binding protein (GC) in cattle. Anim. Genet. 17: 175-182.

Bowling, A.T. (1987). Equine linkage group II: phase conservation of To with $A l^{B}$ and $G c^{S}$. J. Hered. 78: 248-250.

Bowling, A.T. and Clark, R.S. (1988). Excess of heterozygotes at albumin locus in American standardbred horses. Anim. Genet. 19: 331-341.

Chesser, R.K. (1983). Genetic variability within and among populations of the black-tailed prairie dog. Evolution 37: 320-331.

Erhardt, G. and Simianer, H. (1993). Linkage between the loci for serum albumin and vitamin D binding protein (GC) in sheep. Anim. Genet. 24: 301-303.

Foltz, D.W. (1981). Genetic measures of inbreeding in Peromyscus. J. Mammal. 62: 470-476.

Gahne, B. and Juneja, R.K. (1985). Prediction of the halothane (Hal) genotypes of pigs by deducing $\mathrm{Hal}$, Phi, Po2, Pgd haplotypes of parents and offspring: results from a large-scale practice in Swedish breeds. Anim. Blood Groups Biochem. Genet. 16: 265-283.

Gahne, B., Juneja, R.K. and Grolmus, J. (1977). Horizontal polyacrylamide gradient gel electrophoresis for the simultaneous phenotyping of transferrin, post-transferrin, albumin and post-albumin in the blood plasma of cattle. Anim. Blood Groups Biochem. Genet. 8: 127-137.

González, P., Tuñón, M.J. and Vallejo, M. (1987). Genetic relationships between seven Spanish native breeds of cattle. Anim. Genet. 18: 249256.

Hartl, G.B. and Pucek, Z. (1994). Genetic depletion in the European Bison (Bison bonasus) and the significance of electrophoretic heterozygosity for conservation. Conserv. Biol. 8: 167-174.

Jordana, J. and Piedrafita, J. (1996). The "Bruna dels Pirineus" (Pyrenean brown breed): a genetic study of a rare cattle breed in Catalonia (Spain). Biochem. Syst. Ecol. 6: 485-498.

Jordana, J., Piedrafita J., Sánchez, A. and Puig, P. (1992). Comparative F-statistics analysis of the genetic structure of ten Spanish dog breeds. J. Hered. 83: 367-374.

Juneja, R.K., Sandberg, K., Andersson, L. and Gahne, B. (1982). Close linkage between albumin and vitamin D binding protein (GC) loci in chicken: a 300 million-year-old linkage group. Genet. Res. 40: 95-98.

Kidd, K.K., Stone, W.H., Crimella, C., Carenzi, C., Casati, M. and Rognoni, G. (1980). Immunogenetic and population genetic analyses of Iberian cattle. Anim. Blood Groups Biochem. Genet. 11: 21-38.

Li, C.C. and Horvitz, D.G. (1953). Some methods of estimating the inbreeding coefficient. Am. J. Hum. Genet. 5: 107-117.

Mascort, L. (1957). La raza vacuna de las Alberes. Ph.D. thesis, Universidad de Córdoba, Córdoba.

Mason, I.L. (1988). A World Dictionary of Livestock Breeds. CAB International, Wallingford. 
Medjugorac, I., Kustermann, W., Lazar, P., Russ, I. and Pirchner, F. (1994). Marker-derived phylogeny of European cattle supports demic expansion of agriculture. Anim. Genet. 25(S1): 19-27.

Moazami-Goudarzi, K., Vaiman, D., Mercier, D., Grohs, C., Furet, J.P., Leveziel. H. and Martin, P. (1994). Analysis of genetic diversity in French cattle breeds by use of microsatellites: preliminary results. Genet. Sel. Evol. 26: 155s-165s.

Nei, M. (1975). Molecular Population Genetics and Evolution. North-Holland Press, Amsterdam.

Nei, M. (1977). F-statistics and analysis of gene diversity in subdivided populations. Ann. Hum. Genet. 41: 225-233.

Nei, M. (1978). Estimation of average heterozygosity and genetic distance from a small number of individuals. Genetics 89: 583-590.

Nei, M. (1987). Molecular Evolutionary Genetics. Columbia University Press, New York.

Nygren, J. and Rasmusson, M. (1980). Allozyme variation in natural populations of field vole (Microtus agrestis L.). I. Survey of the "Semistable" population in southern Sweden. Hereditas 92: 65-72.

Reynolds, J., Weir, B.S. and Cockerham, C.C. (1983). Estimation of the coancestry coefficient: basis for short-term genetic distance. Genetics 105: 767-779.

Robertson, A. (1965). The interpretation of genotypic ratios in domestic animal populations. Anim. Prod. 7: 319-324.

Ruiz-García, M. (1994). Genetic structure of the Marseilles cat population: is there really a strong founder effect? Genet. Sel. Evol. 26: 317-331.

Sánchez Belda, A. (1984). Razas Bovinas Españolas. Publicaciones de Extensión Agraria, Madrid.

Sandberg, K. and Juneja, R.K. (1978). Close linkage between albumin and GC loci in the horse. Anim. Blood Groups Biochem. Genet. 9: 169-173.

Simon, D.L. and Buchenauer, D. (Eds.) (1993). Genetic Diversity of European Livestock Breeds. European Association for Animal Production, Publication No. 66. Wageningen Press, Wageningen.
Smouse, P.E. and Long, J.C. (1988). A comparative F-statistics analysis of the genetic structure of human populations from lowland South America and highland New Guinea. In: Proceedings of the Second International Conference on Quantitative Genetics (Weir, B.S., Eisen, E.J., Goodman, M.M. and Namkoong, G., eds.). Sinauer Associates, Sunderland, pp. 32-46.

Sneath, P.H.A. and Sokal, R.R. (1973). Numerical Taxonomy. Freeman, San Francisco.

Swofford, D.L. and Selander, R.B. (1989). BIOSYS-1 User's Manual, Release 1.7. A Computer Program for the Analysis of Allelic Variation in Population Genetics and Biochemical Systematics. Illinois Natural History Survey, Champaign.

Takahata, N. (1983). Gene identity and genetic differentiation of populations in the finite island model. Genetics 104: 497-512.

Terauchi, R. (1990). Genetic diversity and population structure of Dioscorea tokoro Makino, a dioecious climber. Plant Species Biol. 5: 243-253.

Trexler, J.C. (1988). Hierarchical organization of genetic variation in the Sailfin Molly, Poecilia latipinna (Pisces: Poeciliidae). Evolution 42: 995-1005.

Waples, R.S. (1987). A multispecies approach to the analysis of gene flow in marine shore fishes. Evolution 41: 385-400.

Weir, B.S. (1990). Genetic Data Analysis. Sinauer Associates, Sunderland.

Weir, B.S. and Cockerham, C.C. (1984). Estimating F-statistics for the analysis of population structure. Evolution 38: 1358-1370.

Weitkamp, L.R., Rucknagel, D.L. and Gershowitz, H. (1966). Genetic linkage between structural loci for albumin and group specific component (GC). Am. J. Hum. Genet. 18: 559-571.

Wright, S. (1965). The interpretation of population structure by F-statistics with special regard to systems of mating. Evolution 19: 395-420.

Wright, S. (1978). Evolution and the Genetics of Populations. Vol. 4. University of Chicago Press, Chicago.

(Received November 17, 1997) 